\title{
THE PROBLEM OF NORMATIVE JUSTIFICATION AND POLITICAL STABILITY IN CONTEMPORARY DEMOCRATIC THEORY:
}

KANT, RAWLS, AND HABERMAS

\author{
MURAT ÖZBANK* \\ Istanbul Bilgi University
}

\begin{abstract}
This paper focuses on the problem of justifying the normative claim to legitimacy and maintaining the stability of democratic political structures under conditions of cultural diversity. The author defines the problem in terms of its theoretical and practical implications and presents exegetical summaries of three philosophical solutions to it: Immanuel Kant's attempt to ground a universalistic philosophy of morality on the assumption of the transcendental unity of practical reason, John Rawls' idea for an "overlapping consensus," and Jürgen Habermas' discourse theoretical grounding of a deliberative model of democracy. The paper concludes with the argument that Habermas' approach is conceptually more sophisticated and practically more relevant when compared with the other two, and, as such, it offers a more promising solution to the problem at hand.
\end{abstract}

Key words: normative justification, political stability, deliberative democracy, political liberalism, Discourse Theory, cultural diversity, Kant, Rawls, Habermas.

\section{ÇA ĞDAŞ DEMOKRASİ KURAMINDA NORMATIFF GEREKÇELENDİRME VE SIYASAL ISTIKRAR SORUNU: KANT, RAWLS VE HABERMAS}

\section{$\ddot{O Z E T}$}

Bu makale, kültürel çeşitlilik koşulları altında demokratik siyasal yapıların normatif meşruiyet iddialarının nasıl temellendirilebileceği ve bu yapıların istikrarının nasıl să̆lanabilece ği sorununa odaklanmaktadır. Yazar, bu sorunu kuramsal ve pratik boyutlarıla tanımlamakta ve bu sorunu çözmeye yönelik üç farklı felsefi yaklaşımın eleștirel ve kıyaslamalı birer özetini sunmaktadır. Bu yaklaşımlar, Immanuel Kant'ın evrenselci bir ahlak felsefesini aşkın aklın birliği varsayımı üzerinde temellendirme çabasl, John Rawls'un “örtüşen görüşbirliğ i fikri” ve Jürgen Habermas'ın tartışmacı bir demokrasi modelini, tartışım kuramında temellendirme çabası olarak özetlenebilir. Makale, Habermas'ın yaklaşımının, diğer iki yaklaşımla klyaslandığında, kavramsal olarak daha gelişmiş ve

* Murat Özbank is an Assistant Professor in the Department of International Relations at Istanbul Bilgi University, 34387, Şişli, Istanbul, Turkey. E-mail: mozbank@bilgi.edu.tr 
pratik olarak da daha uygun bir çerçeve sunduğu, dolayısıla ele alınan soruna daha umut vaat edici bir çözüm getirdiği tezini dile getirerek son bulur.

Anahtar kelimeler: normatif gerekçelendirme, siyasal istikrar, tartı̧macı demokrasi, siyasal liberalizm, Tartı̧ım Kuramı, kültürel çeşitlilik, Kant, Rawl, Habermas.

This paper focuses on two questions: In a diversified society co-habited by different communities of faith and thought, how can we justify the claim that every citizen should accept a democratic conception of justice promising equal freedoms of thought, conscience and speech to every other citizen? How can democratic institutions and processes premised on such a conception of justice be stabilized in a diversified society? These two questions of justification and stability can also be posed as interrelated components of one problem: namely, the problem of reconciling ethical diversity with political unity within a stable and legitimate framework of democratic politics. My goal in this paper is to clarify the sense in which, I think, contemporary political scientists should understand and take this problem seriously when studying questions related to democracy and democratization in complex and diversified societies of late-modernity. To this aim, I first define this problem in terms of its theoretical and practical implications, then I present exegetical summaries of three philosophical solutions to that problem: Kant's attempt to formulate and ground a universal moral law in the unity of human reason, Rawls' idea for an overlapping consensus and Habermas' discourse on the theoretical reconstruction of human rights and deliberative democracy. I argue that in terms of conceptual sophistication and practical relevance, Habermas' approach is the more promising one of these three.

\section{THE PROBLEM}

What Max Weber calls the "plurality of gods and demons" is a phenomenon that can be observed in all modern societies. In such societies different societal actors, who affirm different conceptions of justice associated with different ideological, religious and/or philosophical traditions of thought and/or faith, co-exist and interact with one another in a common time and space, under a common social, political and legal structure. It is, therefore, not surprising that in such societies the following two questions arise: Among the various conceptions of justice that co-exist in society, which one should the common political structure embody? If there is a conflict among different societal actors about the validity of the conception of justice embodied in the common political structure, how can that conflict be resolved without jeopardizing societal peace?

In the contemporary literature on political theory we find two well-defined and time-honored approaches to answer these questions. The first approach is "empirical" and/or "realistic" in its orientation and resonates with the motto "might makes right." It holds that in any society the stability of political institutions and processes is a function of the hegemonic strength of the worldview that favors these institutions and processes. Hence, it suggests that among the various conceptions of justice that co-exist in a diversified society, the conception of justice that the common political structure embodies is likely to be the one that is associated with the culturally hegemonic worldview; and culturally hegemonic is the worldview which succeeds in generating and maintaining a widely shared popular belief in the legitimacy of the type of political structure it favors. ${ }^{(1)}$ 
The second approach, by contrast, is normative in its orientation and attributes equal autonomy to all human beings. In other words, it assumes that all human beings, "without distinction of any kind, such as race, color, sex, language, religion, political or other opinion, national or social origin, property, birth or other status" are " equally endowed with reason and conscience." It further affirms a democratic conception of political justice that grants all citizens equal "freedoms of thought, conscience and speech" while obliging them to "duly recognize and respect the rights and freedoms of others and meet the just requirements of morality, public order and the general welfare in a democratic society." Accordingly, this approach suggests that in a diversified society, the conception of justice that the common political structure embodies ought to be one that all autonomous citizens living under that structure can freely will to accept as valid and that a "democratic" conception of justice, as the one described above, would fill in this slot quite nicely. It further maintains that only a political structure that accords with the autonomous wills of all citizens can claim to be legitimate and only a political structure that can be shown to be legitimate in this specific sense can maintain societal peace among equally autonomous citizens. ${ }^{(2)}$

Now, if we take the perspective of the empirical approach, it would not make much sense for a group of citizens who affirm a worldview other than the one entrenched in the common political structure of the society to demand a justification of the legitimacy of that structure. In other words, it would not make much sense for such citizens to ask: "why should we believe in the legitimacy of a political structure that is based on a conception of justice that does not accord with the worldview we hold?" Asking this question would be pointless, because either the hegemonic worldview that favors the existing political structure is strong enough to hush up such "subversive" questions, in which case the only answer that the dissidents are likely to get is a repressive threat in the form of "believe, or else...", or it is not, in which case what the dissidents need is not a justification but a will to overpower the hegemonic worldview, and change the political structure in the way they want. This means that in the empirical approach the question of normative justification does not arise at all because the effectiveness of a worldview in upholding its hegemony in the minds and hearts of an overwhelming majority of citizens would suffice for it to raise a claim to the legitimacy of the type of political structure it favors.

If we take the perspective of the normative approach, however, no citizen can be expected to believe in the legitimacy of a political structure unless she can be convinced that its conception of justice is one that she can autonomously will to accept as valid. Under a democratic constitution, premised on a conception of justice such as the one described above, this holds particularly true because demanding a justification of the legitimacy of the political structure is a "right" that each citizen has by virtue of his/her autonomy as a human being, just as "recognizing and respecting" that right is an obligation which every other citizen is required to fulfill in good faith. This means that if a group of citizens affirming a different worldview exercise their right to demand a justification by questioning the validity of the democratic conception of justice on which the common political structure is based, other citizens who affirm the democratic worldview may not count simply on their hegemonic strength to hush up such subversive questions. To remain true to their own ethical-existential selfunderstanding, such citizens need to fulfill their self-imposed obligation to "recognize and respect the rights and freedoms of others," and they can do so only by providing a full-fledged justification of the claim that the democratic conception of justice that they affirm is one that all citizens, including those who hold different worldviews, can autonomously will to accept as valid. A failure to provide such a 
full-fledged justification only would result in a mortifying loss of ethical existential self-respect on the part of those who affirm the democratic worldview- mortifying, because according to the democratic worldview, such self-respect in one's own reason and conscience defines the very essence of what it means to be a dignified member of the human family.

A mortifying loss of self-respect, however, is not the only price that a failure to justify the democratic conception of justice would extort in a culturally diversified society. Such a failure also would have disastrous consequences for "public order," for the simple reason that no autonomous human being "endowed with reason and conscience" would freely will to obey a political authority whose claim to legitimacy, she thinks, is "unjustifiable." Even the notions of "hegemony" or "popular belief in legitimacy" that we find in the empirical approach cannot provide functional alternatives to a fullfledged justification in this respect. As Abraham Lincoln once said, "you can fool all of the people some of the time, some of the people all of the time, but you cannot fool all of the people all of the time." And autonomous human beings endowed with reason and conscience indeed would feel fooled, if the only answer they get to the question "why should we believe in the legitimacy and obey the authority of this political structure?" is the repressive threat: "believe or else..." No method of ideological propaganda (or psychological warfare, to use the military terminology) can be effective enough to suppress such questions of "why?" in perpetuity and resistance against perceived injustice would erupt eventually. Obviously, all political structures, including democratic ones, can and do respond to such challenges to their stability, with force if necessary, but then again, there is no method of coercion that effectively can resist resistance against perceived injustice, as the history of modern revolutions of all ideological hues shows. More tragically, as long as the question of "why?" remains unanswered, there is no way to determine who, actually, is resisting injustice: those on the side of the existing political structure or those who seek to change it? In such an encounter both sides would be fighting against perceived injustice without knowing "why," therefore this would be a war of selfrighteous bullies, all victims and persecutors at once.

This means that in the socio-political landscape of a diversified society the theoretical question of normative justification and the practical question of political stability would arise simultaneously, as if they were the reverse sides of the same coin. Any theoretical criticism questioning the legitimacy of the common political structure necessarily would challenge the hegemony of the worldview supporting the stability of that structure; and any serious opposition trying to change an established political structure necessarily would call into question the worldview that owns up that structure's claim to legitimacy. This is why normative theorists of democracy in the tradition of Kant usually pose the theoretical question of justification and the practical question of stability as two interrelated components of one and the same conceptual problem: namely, the problem of reconciling ethical diversity with political unity within a single framework of democratic politics.

\section{KANT: THE UNITY OF PRACTICAL REASON}

Kant is neither the first nor the last thinker in the history of political thought who has posed the problem of "normative justification and political stability" in this interrelated manner, but his philosophy offers, beyond any doubt, one of the most influential solutions to it. Reflected in the Kantian solution to the problem of justification and stability is the ultimate task that Kant sets himself 
as a philosopher: namely the task of discovering the universal and necessary features of human reason, on the basis of which both theoretical claims to the truth of various sciences and practical claims to the truth of various norms of action guiding human behavior can be decided objectively and authoritatively. In the present context, only the latter aspect of Kant's thought need interest us, for the problem of justification and stability falls within the domain of what Kant calls "practical reason."

According to Kant "practical reason" is the common quality that the human species is destined to cultivate in a world-historical process he calls "the enlightenment." This, Kant envisions to be a process of learning, not through the philosophical way of thinking about the role of thinking in human affairs, but through the hard way of trial and error - an onerous and protracted process, to be sure, that would exhaust the lifetimes of several generations in recurrent periods of political upheavals, wars, and economic distress. He is, however, optimistic that mankind gradually will learn to release its "self-incurred immaturity," and reach the point, where he, as a philosopher giving voice to reason, already stands: namely, the point where human actions are guided, not by the subjective desires, particular interests and personal whims of human agents, but by the universal and necessary dictates of human reason. It is this assumption of the teleological commonalty of practical reason, not to this or the other individual living in this or the other social, cultural or historical setting, but to the human species as such, that gives Kant the foundation necessary to venture a solution to the problem of justification and stability as defined above (Kant, 1991a; 1991b; 1991d).

Like many philosophers before and after him, Kant is convinced that normative questions reveal the truth, and hence it is possible to give objective answers to questions of what twentieth century social scientists came to call "moral values." But Kantian moral philosophy does not propose a catalogue of substantive norms of action that members of the human species are expected to accept, on the epistemic authority of the philosopher, as pre-established moral truths. Instead it offers a procedure of moral reasoning by which any rational agent himself can decide whether or not a given norm of action that claims validity in the phenomenal world of human affairs is in accord with the universal and necessary dictates of practical reason, and hence is morally valid. Accordingly, when it comes to the question as to whether or not a norm of action is morally valid, all a rational agent need do is ask her the following questions: Can I even conceive this norm of action, if it were to govern the world, as a law of nature? If I can, then can I rationally will to act on it in such a world?" (Johnson, 2004).

If the norm of action in question is not even conceivable in a world governed by it, that is to say, if it fails the test of the first question, then it is "irrational" and therefore morally wrong. If a norm of action passes the test of the first question, but fails the test of the second question then it is morally wrong, but there may be circumstances in which behavior guided by it can be seen as rational and therefore permissible. If a norm of action passes the tests of both questions, then it is rational and we are duty-bound to accept it as morally valid. This procedure of moral reasoning, Kant thinks, is both "imperative" and "categorical" - imperative because it is derived, as a regulative directive, from practical reason; "categorical," because reason, unlike the subjective desires, particular material interests and past grievances of individual human agents, is not subject to variation across time and space. Thus he calls this procedure the "Categorical Imperative," and formulates it in a number of different ways, all of which, he claims, are different expressions of the same moral law: "Act according to that maxim which you can at the same time will to become a universal law without contradiction" (Johnson, 2004; Kant, 1991c, 2005; Reiss, 1991). 
Now, if the assumption of the teleological commonalty of practical reason to the human species as such is granted, the procedure of moral reasoning established by the categorical imperative indeed can offer a solution to the problem of justification as defined above. Consider, for example, the case of a rational agent who has been born into and raised in a non-Western cultural tradition and who suspects that the universal declaration of human rights is not universal at all, but reflects the particular point of view of the "White Christian European Man." To reassure the skeptic, all that a Westerner needs to do is to run the norms listed in the universal declaration of human rights, one by one, through the test of the categorical imperative as described above. If they pass the test of the categorical imperative, as indeed they do, she can say that the universal declaration is justified from the impartial point of view of the "practical reason" and therefore the suspicions of the non-Western skeptic are "unjustified." In fact, the non-Western skeptic does not even need a Westerner to put his suspicions at rest. To the extent that he is a rational agent, he can abstract his mind from the particular cultural tradition and/or historical circumstances within which he has cultivated his suspicions and submit the issue to the judgment of practical reason, all by himself. If he does then he will arrive at the same conclusion about the validity of the universal declaration that any other rational agent would, because "practical reason," unlike culturally and historically specific worldviews, is not subject to variation across time and space.

Not only the problem of justification, but the problem of stability too finds its Kantian solution in this assumption of the unity of practical reason. The key in this respect is the "rationalization" of society. If we look from the perspective of an individual citizen, a society can be "rationalized" in two interrelated senses: First, "internally," the individual members of the society in question themselves can become rational. An individual (or a group of individuals) can be said to be rational in this "internal" sense, to the extent that they can make "public use of their own reason, in all matters ...without outside guidance" (Kant, 1991a:54). This, as we can remember, is what Kant calls an "enlightened society" - a society, in other words, of "autonomous" individuals who can reflect upon the morality of their own actions, and if necessary, exercise self-restraint in their public interactions with other individuals, so that their "wills can reconcile with the wills of others according to a universal law of freedom." Second, "externally" the constitutional and legal order of the society in question can be rationalized. A society can be said to be rational in this "external" sense to the extent that the constitutional and legal principles that govern it as a whole accord with the dictate of practical reason, namely the "categorical imperative." This, Kant calls, a "state of right" - a state, in other words, that is governed by "external laws" in "which the will of one person can be reconciled with the freedom of the other, according to a universal law" (Kant, 1991c: 133-134).

Now, once a society is rationalized in these two interrelated senses, the problem of stability either does not arise at all, or, if it does, it can be solved easily, because any conflict stemming from different claims to moral rightness can be settled easily by recourse to the impartial judgment of "practical reason." In such recourse, practical reason would operate either internally, through the autonomous wills of individual members, or externally, through formally institutionalized processes and mechanisms of legal adjudication and law-enforcement. In the first case, by making use of their own reason, individual members, as rational agents, would themselves reflect on the rationality of the particular norms and values associated with the particular cultural tradition into which they have been born or with the particular (religious or ideological) worldview they adopt. If, after such reflection, it transpires that they cannot will a particular norm to become a universal law without contradiction, they will refrain on their own from proposing it for general adoption. Thus in an "enlightened society" 
of "rational individuals" the problem of stability would not arise at all, because in such a society individual members can reflect themselves on the justifiability of a norm of action proposed for general adoption by society as a whole, and drop or adopt it of their own free will without further ado.

Even in an enlightened society, however, there still may be some "immature" individuals who cannot, for some reason, maintain their autonomy toward the particular cultural tradition into which they have been born, or the particular worldview that they, somehow, have come to adopt. The lack of autonomy on the part of such individuals means that they cannot use their own reason to evaluate the validity of particular claims to moral rightness raised by such traditions and/or worldviews, and therefore they cannot exercise self-restraint when it comes to a conflict between a maxim of action that they subjectively claim to be right on the one hand, and another maxim of action that practical reason establishes as universally and necessarily valid on the other. It is, therefore, quite conceivable that such "irrational" individuals may jeopardize societal peace in a diversified society. They may, for example, pursue "irrational" political goals and even engage in acts of violence against other individuals who do not share their particular conception of "right." But in a "rational" society even in these cases political stability would not emerge as a worrisome problem because practical reason would still operate as an arbiter. This time it would operate externally, however, through the medium of positive laws that can authorize the use of coercive measures against individuals who pursue "irrational" political goals and/or engage in violent acts in that pursuit.

Such use of legally authorized force would be legitimate according to Kant, because "[r]ight entails the authority to use coercion... If a certain use to which freedom is put is itself a hindrance to freedom in accordance with universal laws (i.e., if it is contrary to right), any coercion used against it will be a hindrance to a hindrance of freedom, and will thus be consonant with freedom in accordance with universal laws - that is, it will be right" (Kant, 1991c: 134). Thus, in a "state of right" the problem of stability, if it arises at all, can easily be solved, because such a state is governed by generally applicable positive laws that can be enforced through coercive measures, if necessary. Furthermore, such use of coercive measures can be seen as objectively "legitimate" to the extent that the laws that authorize them are in accord with a constitution of which the positive principles of right are "justifiable" in the higher court of practical reason.

The solution to the problem of justification and stability that we find in Kant's philosophy is indeed elegant and the internal consistency of the conceptual architectonic that spells out that solution is impressive. But, alas, a conceptual architectonic is only as strong as its fundamental assumption, which in Kant's case is the assumption of the unity of practical reason. What if that assumption does not hold water, as indeed a number of post-Kantian philosophers starting with Hegel, Nietzsche, and Heidegger and later Gadamer, Foucault, Derrida, and Lyotard, to name a few, argue that it does not? What if "practical reason" is embedded in and imbued with the historical context in which it is used, and if different agents, coming from different traditions of thought, can quite reasonably, give different answers to one and the same practical question depending upon the perspective they adopt? What if practical reason is as much subject to variation across time and space, as culturally and historically specific worldviews are? What if the assumption of the unity of practical reason itself is nothing more than a particular worldview that happened to gain prominence in a particular historical period and in a particular cultural setting? Can we, then, still subscribe to the Kantian solution to our problem? 
Obviously we cannot. Dropping the assumption of a unified practical reason would mean admitting that what we deal with is, in fact, a "plurality of reasons," each taking its particular color, its particular substance, from the particular historical, cultural, or socio-political contexts in which it is employed and/or from the particular circumstances and/or perspectives of the agents who employ it. This, however, fundamentally undermines the claim that in a culturally diversified society "practical reason" can be trusted to operate, either internally or externally, as an "objective" arbiter when it comes to a normative conflict between a democratic conception of justice, on the one hand, and a different, contradictory claim to moral rightness on the other. True, using the procedure proposed by Kant, one very well can develop an argument justifying the universality of human rights or the use of coercive measures to maintain the stability of a democratic political system premised on them. But if we admit that "practical reason" is "context dependent" and "plural" we also must admit that such an argument can convince only one particular group of people among many others that co-exist in a culturally diversified society. This would be the group of "Kantian liberals" - that is to say, the group of those who already have adopted the Kantian perspective as a particular worldview - because only they would think that the reasons given for the adoption of human rights as a common set of maxims by the society as a whole, are indeed "good reasons." Others, who were born into or have come to adopt a different philosophical, religious, or ideological tradition of thought, would remain unimpressed by such an argument. They would remain unimpressed, not because they are unreasonable and therefore irrational, but because they are differently reasonable and yet rational. After all, it is quite conceivable that these "others" too can offer an analytically precise and logically coherent argument to refute human rights and adopt in its place a different, conflicting set of maxims as fundamental constitutional principles for society as a whole. Obviously the reasoning process they would employ for that purpose, as well as the reasons they would give to support that proposal (or to use coercive means to pursue that proposal as a political goal) would be different from the procedure proposed by Kant, but under the assumption of the plurality of reasons, their argument would not be less rational for that.

Now, in the contemporary literature on democratic theory, we find basically two different responses to this contextualist critique of the Kantian assumption of the unity of practical reason. Some think that we should simply admit defeat and drop the question of justification from the philosophical discourses on democracy altogether. Thus, for example, Richard Rorty, who is one of the most eloquent and provocative authors giving voice to the contextualist critique in democratic theory, argues that there simply is no context-independent metaphysical assumption on the basis of which we can develop a non-circular argument endorsing human rights and democracy as everyone's common ground. If this means that such democratic values as free speech, tolerance, and reciprocity cannot be justified as universal moral truths and we would have to fall back on the "realistic" approach to maintain the stability of democratic political structures entrenching those values, so be it. A pragmatic conception of moral truth, as in William James' phrase that "truth is what is good for us to believe," would suffice for us to affirm, support, and defend democracy. Democratic values are, after all, "our" values, embedded in "our" particular political culture, and the fact that we cannot demonstrate their validity in other socio-cultural and/or historical settings is no reason for us to stop believing in them as our particular moral truths. What contemporary theorists of democracy need is, therefore, not a metaphysical foundation on which they can develop a justification of democratic values as universal moral truths, but therapeutic relief from the existential agony that they feel when the contextualist critique confronts them with the harsh reality of their particularity (Rorty, 1979; 1989; 1991; 1998). 
Admitting the particularity of democratic values and dropping the question of justification from the theoretical discourses on democracy altogether is one of the two possible responses to the contextualist critique. The other response is based on the more plausible view that ignoring a problem at the theoretical level does not necessarily make it disappear at the practical level, and since in diversified societies theoretical questions of normative justification emerge hand in hand with the practical problems of political stability, we may as well agonize a little longer before allowing ourselves to become sedated by the blissful relief offered by the pragmatic view. It may well be true that the contextualist critics have a point in arguing that the Kantian assumption of the unity of practical reason cannot offer a solid foundation to solve the problem of normative justification under the conditions of cultural diversity, but the failure of $a$ solution to a problem does not render the problem itself irrelevant. Instead of dropping the problem of justification altogether, therefore, it may be a better idea to try to find a new solution to it, one that takes the contextualist critique seriously, but does not admit defeat readily in justifying democracy. This, at least, seems to be pretty much the view that John Rawls and Jürgen Habermas share, despite the many differences that they have in the respective solutions they offer to the problem of justification and stability.

\section{RAWLS: THE IDEA FOR AN OVERLAPPING CONSENSUS}

The best way to summarize Rawls' views on the problem of justification and stability is to divide them into two phases as marked by the publication of A Theory of Justice (1971), and a series of articles ${ }^{(3)}$ which culminated in the publication of Political Liberalism (1993), respectively. In the early phase, Rawls appears to be a straightforward Kantian political philosopher who still has not lost his confidence in the assumption of the unity of practical reason. This is evident in the fact that in $A$ Theory of Justice he develops a procedure of moral reasoning, in the form of a simple thought exercise, to answer the perennial question of political theory: what is a just - or, in Rawls' own words, "well-ordered society"? The thought exercise Rawls proposes to answer that question invites us to imagine ourselves in a hypothetical pre-social situation, which he terms "the original position," where we are charged with the task of determining the principles of justice that will govern the society in which we are going to live. We are expected to accomplish this task behind a "veil of ignorance," which can best be understood as a device that helps us in putting ourselves in the shoes of other - less or more advantaged - persons, when reflecting upon the question of justice.

This works as a conceptual filter that allows us to understand what sort of social advantages (or disadvantages) are associated with certain personal characteristics, such as wealth, health, and strength, but prevents us from knowing which of those characteristics we personally posses. In other words, behind "the veil of ignorance" we know what it means to be rich or poor, weak or strong, healthy or unhealthy in social life, but we do not know whether we are going to be personally rich or poor, etc., once we start living in society. Now, Rawls' strong universalistic claim in A Theory of Justice is that anyone who seeks to define justice under these assumptions would arrive at a conception of justice that is "fair" for everyone, and the following two principles of what he calls "justice as fairness" offer such a conception. Accordingly, in a "well-ordered" society, Rawls claims: ${ }^{(4)}$

Each person should have an equal claim to a fully adequate scheme of equal basic rights and liberties, which scheme is compatible with the 
scheme for all, and in this scheme the equal political liberties, and only those liberties are to be guaranteed their fair value.

Social and economic inequalities are to satisfy two conditions: First, they are to be attached to positions and offices open to all under conditions of fair equality of opportunity; and second, they are to be to the greatest benefit of the least advantaged members of society. (Rawls, 1993: 5-6)

It must be clear even from this synopsis that Rawls seems to intend the thought exercise he proposes in A Theory of Justice to serve two simultaneous purposes at once: For one thing, the conceptual constructs of an "original position" and "the veil of ignorance" function to bring the various democratic norms and values that are found in the political cultures of "advanced liberal societies" in a "reflective equilibrium," which Rawls then formulates in the more economical form of two substantive principles of "justice as fairness." For another, the same procedure that allows Rawls to define the conception of "justice as fairness" also justifies that conception as a universal moral truth accessible to anyone who follows that procedure. Without the assumption of the unity of practical reason underpinning it, however, this second, justificatory dimension of the procedure of reasoning proposed by Rawls would not make much sense at all. It is, therefore, not surprising that after the publication of A Theory of Justice, contextualist authors criticized Rawls in much the same way as they did Kant. Citing one question that political scientist Allison Dundes Renteln (1990) asks should suffice to summarize the gist of these criticisms: How can Rawls assume, even under the factually observed conditions of cultural diversity on the face of the earth, that "everyone thinks the same" when it comes to normative questions of justice?

It is only in his second major work, Political Liberalism, that Rawls admits the fairness of such questions. In a democratic society, he concedes, no one thinks the same, nor is it desirable that they do so, for in a democracy that promises equal freedoms of thought, conscience and speech to all citizens, such diversity emerges as an inevitable fact of social life, namely, "the fact of reasonable pluralism." There are certain problematic formulations in A Theory of Justice, he further concedes, which create the impression that his understanding of political liberalism is based on a metaphysical claim to truth that discounts this plurality of reasons. Rawls claims, however, that this is not what he actually thinks, for in a democratic society "the fact of reasonable pluralism" can neither be discounted nor suppressed, except perhaps by risking intense human suffering and this is certainly not what political liberalism proposes.

It is with the recognition of "reasonable pluralism" as a social fact that the second phase in Rawls' thinking starts. In this phase, Rawls tones down his confidence in the Kantian assumption of the unity of practical reason and sets out to develop the innovative new solution to the problem of justification and stability mentioned above. Central to this new solution is a conceptual distinction that Rawls introduces between "comprehensive" philosophical or religious doctrines on the one hand, and political liberalism as a "free-standing," "political" view on justice, on the other. Accordingly, "comprehensive doctrines" show two typical characteristics which, in Rawls' understanding, "political liberalism" does not. First, comprehensive doctrines aspire to regulate and/or explain human life in all its aspects - from personal, familial and spiritual, to social, economic, cultural and political - in one coherent conceptual framework. Second, they owe the coherence of their conceptual architectonics to a unique metaphysical and/or philosophical assumption that excludes other claims 
to truth raised by other comprehensive doctrines. In this sense, all religious belief systems, as well as such "secular" worldviews as utilitarianism, Marxism and Kantianism, fall within the category of comprehensive doctrines. The existence of God in the case of religious doctrines, the principle of utility in the case of utilitarianism, the primacy of human labor in the case of Marxism, and the transcendence of human reason in the case of Kantianism can be seen as so many religious or philosophical assumptions, on the basis of which these different "comprehensive doctrines" raise their mutually exclusive claims to truth.

In contrast, political liberalism introduces "justice as fairness," not as a comprehensive theory of morality, but as a sharply focused conception of justice that is applicable only to the limited scope of the "basic political structure" of a society. As such, it seeks to regulate only the organization and functioning of basic constitutional institutions, the actions and decisions of elected and/or appointed public officials staffing those institutions, the conduct of candidates running for public office, and nothing else. Furthermore, when introducing "justice as fairness" in this sharply focused political sense, political liberalism does not lean on a unique metaphysical and/or philosophical assumption, about, say, the mysteries of human existence or the innate qualities of human nature or even the transcendence of human reason. Rather, political liberalism introduces justice as fairness as a "freestanding view," which means that it deliberately refrains from raising a philosophical claim to its "fundamental truth." Political liberalism, argues Rawls, leaves philosophical questions of truth "as they are." Therefore, from the perspective of political liberalism "justice as fairness" is just one political conception of justice among many others, and nothing more. This means that the conceptual constructs of an "original position" and the "veil of ignorance" help us in reflecting upon, defining and formulating the two principles of justice as fairness, but not in establishing them as universal moral truths. In other words, these conceptual constructs serve political liberalism as "analytical tools of exposition," but not as philosophical tools of metaphysical justification.

If political liberalism, as a free-standing view, deliberately avoids questions of fundamental truth and leaves philosophy as it is, how then, Rawls suggests, does it solve the problem of normative justification and political stability under conditions of reasonable pluralism? Rawls' innovative suggestion in this respect involves lifting the burden of normative justification from liberal political theory and shifting it onto the various comprehensive doctrines, more specifically onto the various claims to fundamental truth associated with them. Key to this solution is the notion of an "overlapping consensus," which is premised on the idea that since justice as fairness is a "free-standing conception" without a unique claim to fundamental truth of its own, it can be supported by as many different philosophical or religious justifications as there are "reasonable" comprehensive doctrines coexisting side-by-side in the socio-cultural landscape of a diversified society. Obviously, all of these various justifications would be different and even incommensurable in their fundamental assumptions regarding philosophical questions of truth or religious questions of faith, but they would still "overlap" in endorsing justice as fairness as a valid conception for everyone. Thus, for example, there may be Kantian, Utilitarian, Marxist, Catholic, Protestant, Sunni and Shi' a justifications of "justice as fairness" and different citizens, affirming these different "comprehensive doctrines," can all accept it, on the basis of these various philosophical or religious justifications, as a valid conception of justice for all.

These citizens certainly would disagree with one another as to "why" they accept "justice as fairness" as a valid conception of justice, but for the particular reasons of their own on which they disagree, 
they would nonetheless agree that justice as fairness is a valid conception. Under such an "overlapping consensus" philosophical and religious disputes between the adherents of various comprehensive doctrines would not cease to exist - they would go on in the "background culture" of the civil society - but such disputes would not reflect on the claim to legitimacy, hence on the stability of the basic political structure. They would not, because citizens' actions and interactions in the political domain would be guided by a common conception of justice which they all accept as valid for different reasons; and any normative conflict regarding the legitimacy of the basic political structure that may arise between them easily could be resolved by reference to that common conception. Furthermore, the democratic political regime even could use force when necessary to defend itself against unreasonable political movements threatening its stability, and as long as it is supported by an "overlapping consensus," the particular claims to fundamental truth associated with various comprehensive doctrines themselves would ground the legitimacy of such use of force in defense of democracy. ${ }^{(5)}$

To summarize, then, in Political Liberalism Rawls makes a number of concessions to the contextualist position, but the solution he offers to the problem of normative justification and political stability still retains a Kantian nucleus. He admits that "reasonable pluralism" is an inevitable and undeniable social fact in all democratic societies, tones down his confidence in the assumption of the unity of practical reason, and insists that "justice as fairness" must be understood as a "freestanding" political conception of justice without a philosophical claim to universal truth of its own. Each of these moves signifies a major digression from the strict Kantian framework, and brings Rawls closer to the contextualist position. But still, by introducing the innovative idea for an "overlapping consensus," he succeeds at keeping the Kantian notion of political legitimacy - namely legitimacy defined as normative justifiability from the perspective of free and equal citizens - at the core of his account of political stability.

\section{HABERMAS: COMMUNICATIVE REASON AND DELIBERATIVE DEMOCRACY}

The solution Rawls offers is indeed elegant and innovative, but not every theorist of democracy is convinced that it is flawless. Jürgen Habermas, for one, is of the opinion that Rawls leaves too much ground to the contextualist position. True the "plurality of gods and demons" is a phenomenon that can be observed in all modern societies and therefore it should be taken into account when developing a theoretical model of political stability under modern conditions. But does this undeniable fact of pluralism necessarily mean that all that is left for a political theorist on which to ground the legitimacy of modern democratic political structures are the divergent claims to moral truth associated with various ideological or religious worldviews? True, by giving up on the assumption of the unity of practical reason and depriving democratic theory of a philosophical claim to truth of its own, Rawls enhances the inclusiveness of democratic political structures. But is this the only way to include the non-western, non-white, non-Christian, non-male "others" in the modern processes of democratic will and opinion formation as free and equal participants? Habermas thinks that there is another way - one that can "include the other" (Habermas, 1998a) without requiring democratic political theory to surrender such notions as "truth" and "reason" to the contextualist critics. ${ }^{(6)}$ 
Now, in Habermas' view, much of what passes as a critique of practical reason in contemporary social and political thought is, in fact, not a critique of practical reason as such, but a critique of only one of its dimensions: namely, instrumental reason. In the "instrumental" sense, practical reason usually is defined as a mental faculty that guides our thinking when calculating the most effective and efficient means to achieve a given end. It offers a subject-centered criterion to evaluate the mental processes and/or actions of individual human agents as "rational" or "irrational" depending upon whether or not these mental processes and/or actions spell out and/or put into practice the most effective strategies to achieve given ends. Contextualist critics equate this "strategic" conception of "instrumental reason" with "practical reason" as such and maintain that "reason" can guide us in developing effective strategies to achieve our chosen goals, but not in making ethical choices between different goals. To make ethical choices between different goals, they argue, we need to have something more, something that precedes and guides our faculty of practical reasoning, namely an ethical sense of "the good" which we can attain only by living in community with other human beings sharing a tradition of common values. Without a prior understanding of this inter-subjectively shared sense of "the good" even the most rational among us would be lost when making ethical choices in social life. This is also why, contextualist critics argue, rationalistic approaches in moral and political philosophy cannot be expected to deliver what they promise: namely, access to universal moral truths by way of a procedure of practical reasoning alone.(7)

Habermas agrees that this contextualist critique has some merit, but only to the extent that it applies to the instrumental dimension of practical reason. There is, however, another dimension of practical reason which neither Kant nor the contextualist critics of Kantian rationalism in moral and political philosophy have ever taken into consideration: namely, communicative reason. Unlike its instrumental counterpart, communicative reason refers not to a mental, but to a linguistic faculty. It is realized not in the mental processes or strategic actions of individual human subjects, but in the communicative processes in which two or more human subjects use language in its most primal mode, namely, to understand one another by speaking with one another. Communicative reason is, therefore, not a subject-centered, but an inter-subjective faculty, and the yardstick it offers allows us to classify not the strategic actions of individual human agents, but their communicative inter-actions with one another as "rational" or "irrational," depending upon whether or not these interactions foster inter-subjectively shared common understandings between them. Thus defined, "communicative reason" is fairly impervious to contextualist criticisms because it resonates with the same socioontological assumption that contextualist authors take for granted: namely, the assumption that all societies, modern or primitive, owe their cohesion to an inter-subjectively shared consensus on a common set of norms and values. In the ordinary cycle of life, this consensus allows the members of a society to coordinate their actions and interactions with one another harmoniously, without any serious clashes. In such cases "communicative reason" operates silently in the background by facilitating the reproduction and transmission of the inter-subjective consensus underpinning this harmony. Occasionally, however, a conflict regarding the validity of a norm of action breaks this harmony and the communication between the members of the society takes on a more reflexive quality. In situations like this "communicative reason" operates more visibly by allowing the parties to the dispute to restore the broken consensus between them, in and through a process of reasoned argumentation. In either case "communicative reason" plays a decisive role in maintaining societal harmony: in one case it facilitates the reproduction and transmission, and in the other the restoration of the background consensus which guides the actions and interactions of the members of the society in the "inter-subjective life-world" that they all share (Habermas, 1984, 2001). 
Now, Habermas grounds his dialogical theory of morality, namely "discourse ethics," on this intersubjectivistic conception of communicative reason (Habermas, 1990b, 1993a). Like Kant's rationalistic philosophy of morality, Habermas' discourse ethics too starts from the assumption that normative disputes can be resolved impartially, on reasons that all can accept as valid and a procedure of practical reasoning can lead our thinking to that resolution. But the procedure proposed by Kant, namely the categorical imperative, is premised upon the subject-centered conception of practical reason, and as such, it outlines a monological process of reasoning: Accordingly, $I$ can consider a disputed norm of action to be valid for every one else, if I can will it to be a universal law without contradiction. Discourse ethics, by contrast, is premised upon the inter-subjectivistic conception of communicative reason and therefore it shifts the emphasis "from what each can will to be a universal law without contradiction, to what all can will in agreement to be a universal norm" (Habermas, 1990a: 67), Thus, in discourse ethics, a dialogical procedure of moral argumentation replaces the monological process of reasoning outlined by the categorical imperative. Accordingly, the "principle of discourse ethics" reads as follows:

Only those norms can be considered to be valid that meet (or could meet) with the approval of all affected in their capacity as participants in a rational discourse. (Habermas, 1990a: 66)

The procedure proposed by Kant is monological, in the sense that when it comes to testing the validity of a disputed norm of action, it requires us to abstract our minds from the concrete circumstances in which the dispute has arisen and to follow the guidance of the categorical imperative unflinchingly, without letting anything or anyone else distract our thinking. The subject-centered conception of practical reason as a transcendental mental faculty renders an actual process of intersubjective argumentation redundant. In other words, even if we do not actually communicate, consult, or argue with any other party to the dispute, our reasoning in the abstract is supposed to be able to guide us to a "universally valid" conclusion. The procedure proposed by Habermas, by contrast, is dialogical because it requires us to test the validity of a disputed norm of action in a "rational discourse" where all affected seek to reach a "rationally motivated" agreement "through the unforced force of the better argument." Therefore, discourse ethics does not allow us to reach a conclusion about the validity of a disputed norm of action without actually taking into account the different cultural, social and economic circumstances and/or perspectives of all those others for whom that norm claims validity.

As mentioned above, Kant grounds the authority of the Categorical Imperative on the assumption of the transcendental unity of practical reason. The above-mentioned principle of the discourse ethics, by contrast, is the more economical formulation of a principle of "Universalization" which Habermas introduces as a linguistic rule of practical argumentation:

Every valid norm must fulfill the following condition: (U) All affected can accept the consequences and the side effects its general observance can be anticipated to have for the satisfaction of everyone's interests (and these consequences are preferred to those of known alternative possibilities for regulation). (Habermas, 1990a: 65) 
This principle of universalization, in turn, is derived from the unavoidable presuppositions that every "communicatively competent" human subject makes whenever she engages in a rational discourse with other human subjects. ${ }^{(8)}$ The following are a few examples that Habermas gives of such presuppositions:

1. The logical-semantic level.

1.1 No speaker may contradict himself.

1.2 Every speaker who applies predicate $\mathrm{F}$ to object $\mathrm{A}$ must be prepared to apply $\mathrm{F}$ to all other objects resembling $\mathrm{A}$ in all relevant aspects.

1.3 Different speakers may not use the same expression with different meanings.

2. The procedural level.

2.1 Every speaker may assert only what he really believes.

2.2 A person who disputes a proposition or norm not under discussion must provide a reason for wanting to do so.

3. The process level.

3.1 Every subject with competence to speak and act is allowed to take part in a discourse.

3.2 a. Everyone is allowed to question any assertion.

b. Everyone is allowed to introduce any assertion whatsoever into the discourse.

c. Everyone is allowed to express his attitudes, desires and needs.

3.3. No speaker may be prevented, by internal or external coercion, from exercising his rights as laid down in 3.1 and 3.2. (Habermas, 1990a: 87-91)

Taken together, these presuppositions outline an "ideal speech situation" which can never be fully achieved in real life, but which we "counterfactually" presume to exist whenever we participate in a rational discourse. In fact, we would not participate in a rational discourse at all if we could not presume that the appropriate conditions of such an "ideal speech situation" are fulfilled to a sufficient degree. Thus, for example, we would not take an argument seriously "if certain questions, contributions or issues are likely to be suppressed, or if agreement or disagreement is likely to be manipulated through insinuations or threat of sanctions, etc." (Habermas, 1993b). Seen in this light, "the ideal speech situation" cannot and should not be understood as a "regulative ideal" that participants in a rational discourse ought to seek to approximate in real life situations. The "ideal speech situation" refers, rather, to the "counterfactual" presuppositions that all communicatively competent human subjects always, already and unavoidably make, whenever they engage in a rational discourse with other human subjects (Habermas, 1979; 1993b: 57). Therefore, Habermas argues, it is impossible to refute the validity of the above-mentioned discourse principle (more specifically the principle of universalization, of which the discourse principle is the more economical formulation) in a rational discourse without falling into a performative contradiction - without, in other words, presupposing that which one seeks to refute in the discourse (Habermas, 1979; 1990a: 79-82). 
Now, this dialogical theory of morality lays down the groundwork on which Habermas develops a normative model of deliberative democracy (Habermas, 1996). He tailors this model specifically for the integration needs of the densely populated, socially, economically and administratively complex, and culturally, ethnically, ideologically and religiously diversified societies of late-modernity. ${ }^{(9)}$ The model has four structural components: "A core area," "a peripheral area," a "public sphere," and a constitutional and legal order premised on human rights and freedoms. The core area comprises three formally organized and functionally differentiated institutional complexes that can be found in all late-modern societies: namely, legislative, executive and judiciary institutions. A constitutionally structured and legally instituted system of "sluices" through which political power and influence flows, connects this "core area" to the "peripheral area" where the informally organized voluntary organizations of the "civil society" are located. These voluntary organizations are enmeshed in the "life-world" of the citizens, and as such they function as the sounding board for societal issues which either require new legal regulations and/or policies or a change in the existing ones. These organizations also form the institutional basis of the third component of the model, namely the "public sphere." Habermas defines the "public sphere" as a complex, unregulated, informal "network of communication for the exchange information and opinion" (1996: 360). As such, it depends upon a continuous flow of expert information on issues of public interest, a vibrant and dynamic civil society that feeds this information and unfettered access to electronic and print media that distributes this information. Finally, the last component of the model, namely a constitutional and legal order premised on human rights and freedoms, not only sets up the formal institutions of the "core area," but also protects the basic political freedoms of the citizens in the peripheral area.

The functioning of the model can be understood best in terms of an input-output loop in which political influence and power is generated, transformed, used, fed back into the loop and reviewed in terms of its use. On the input side, the loop starts in the periphery with the identification of common societal problems that require common societal solutions. Both in identifying thus-far unrecognized societal problems and in developing new and imaginative solutions to them, the voluntary organizations of the civil society play a significant role. They bring such problems (and/or alternative solutions to them) to public attention in and through the informal communication networks of the "public sphere." The ensuing public debates in the electronic and print media result in the formation of topically specific bundles of public opinion on different societal issues. The "influence" of the public opinion thus formed is transmitted through a variety of constitutionally structured and/or protected "sluices," such as party competition and regular elections, collective or individual petitions, etc., to the core area, more specifically to the deliberative forums of the parliament. There, formally structured parliamentary debates transform the "influence of the public opinion" into one of the two basic forms of political power, "communicative power."

Communicative power reflects the deliberatively generated common political will of free and equal citizens on issues of common interest. As such, it has an "authorizing" and "reviewing" capacity over executive institutions. On the authority taken from the parliament, these institutions transform "communicative power" into the second basic form of political power, namely "administrative power" and use it to enforce and/or implement social programs, laws, and/or public policies. The legislative and/or policy "outcomes" thus generated feed back as inputs into the public debates in the peripheral area, where they are evaluated with respect to the consequences of their actual implementation and/or enforcement. The ensuing public debates result in a revised and better- 
informed public opinion which, if need be, re-initiates the process to bring about any necessary changes in the relevant laws and/or policies (Habermas, 1996: 341-387).

As can be gathered from this brief outline, Habermas' model owes its "democratic" character to the direction that the flow of political power follows. As long as power flows from the communicatively formed public opinion of free and equal citizens via the communicative power of the parliament to the administrative power of executive institutions, the citizens can be said to enjoy "public autonomy" in governing themselves and the system retains its democratic character. A "reflux of power" in the opposite direction, however, would mean a loss of public autonomy on the part of the citizens, and as such it would impair the democratic character of the system. There are a number of circumstances under which this may occur, but three special cases are worth mentioning here, for they are the most frequently observed forms of such refluxes in late modern societies. A "reflux of power" may occur, first, in cases where certain actors pursuing non-generalizable social interests, such as profit-oriented business and/or media conglomerates, push for the adoption of publicly unjustifiable societal policies and/or laws by exerting a non-public influence on the law and policy-making processes in the core area. They can exert this influence either directly, for example, by distributing personal benefits to the members of the parliament and/or government officials; or indirectly, by manipulating the communicative processes in the public sphere to bias the "public opinion." Such manipulations of the public opinion also may involve certain law enforcement and/or policy implementing agencies in the core area. In an attempt to "manufacture" a favorable public opinion for a policy which would not hold water if citizens were allowed to hear all relevant and available information on the matter, such agencies, either on their own, or under the influence of a non-generalizable social interest, may use their "administrative power" in an "unauthorized" manner, to restrict access to and/or feed misinformation into the communication networks of the public sphere.

A similar reflux of power may occur if the "administrative complex" in the core area gains autonomy and/or predominance vis-à-vis the communicative power of the parliament and becomes immune to the influence of public opinion. This is a common occurrence in societies with authoritarian political structures, but it also may be observed in societies boasting democratic political structures - it may, because the irreducible complexities of social and economic issues that confront late-modern societies often require the application of sophisticated technical expertise for their mastery. As mentioned above in Habermas' model of deliberative democracy, expert input both in public and parliamentary debates are welcome as contributions, for they give the "lay" citizens in the public sphere, as well as their representatives in the parliament, a better-informed idea when forming opinions on the possible consequences of different policy alternatives. This does not mean, however, that "lay" citizens can be excluded from the loop of societal decision-making, or that their representatives in the parliament can be deprived of their authorizing and reviewing capacities over the administrative complex, so that their expert agencies in the core area can formulate and implement public policies on their own, without interference. It does not because this would reverse the flow of power and transform deliberative democracy into an unaccountable technocracy.

In Habermas' model, it is the third institutional complex in the core area, namely the judiciary, that protects the citizens against such intrusions in their public autonomy. The judiciary performs this function through a formally structured system of impartial constitutional and legal review. Thus, for example, supreme courts check the constitutionality of the statutes passed and authorizations issued by the parliament, and administrative courts check the legality of the "administrative power" used by 
executive and administrative agencies. In performing this reviewing function, judicial institutions derive their authority from and are guided by the provisions of a constitution premised upon a "system of rights" (Habermas, 1996: 132-193). In Habermas' account, this system includes the civil, political, social, economic and cultural human rights that are familiar from such international documents as the Universal Declaration of Human Rights, or the European Convention of Human Rights.

Typically contextualist authors interpret such catalogues of rights as reflective of the cultural and historical biases of the "Western" societies. As can be expected, however, Habermas disagrees and interprets them linguistically and inter-subjectively, in the light of the universal and necessary presuppositions of reasoned argumentation. Accordingly, he construes them as those rights that free and equal citizens in a complex and diversified modern society must grant to one another in order to be able to regulate their collective social life legitimately, in reasoned deliberation with one another (Habermas, 1996: 118-131). Interpreted in this discourse theoretical fashion, human rights show a "Janus-faced" character. On the one hand, they show the features of "moral norms," for human rights have a claim to universal validity that extends beyond the particular context in which they find expression in concrete historical time and socio-cultural space. On the other hand, however, they show the features of positive legal norms, because human rights gain effectiveness only in particular constitutional and legal orders that set up modern democratic political structures. Therefore, Habermas' considers "law and morality" to be mutually and reciprocally constitutive categories in modern democracies and assigns them different but complementary roles in his model of deliberative politics.

Seen as positive legal norms in a particular constitutional order, human rights underpin the institutionalization of the channels that connect the peripheral area to the core area, ensure that political power flows steadily, without refluxes, from the former to the latter, and make certain that the "public sphere" remains free of structural constraints and unilateral manipulations distorting the communicative processes in which citizens form their public opinion. Seen as moral norms, they lay down the normative foundations of the model, and as such they ground the claim to the legitimacy of the democratic political structures and processes. Thus understood, human rights bestow on judicial institutions both a "constitutional" and a "moral" duty to protect the public autonomy of the citizens by using their above-mentioned reviewing powers. They do not, however, authorize them to assume an autonomous legislative capacity when performing this reviewing function. On the contrary, they ensure that the ultimate legislative power, including the power to change the constitution, rests with the parliament, and that the communicative power of the parliament remains under the influence of the "deliberatively formed" public opinion of free and equal citizens, at all times. ${ }^{(10)}$

To recap, then, Habermas' model of deliberative democracy is structured by a system of constitutional and legal "sluices" through which political influence and power flow. The process starts with the formation of opinion in the public sphere, the influence of which is transformed into communicative power in the parliamentary complex, which, in turn, authorizes executive institutions to transform communicative power into administrative power and use it to implement and/or enforce social programs, legal regulations and/or public policies. The legislative and/or policy outcomes thus generated feed back into the loop and become subject to revisions demanded either by judicial institutions or by a better informed public opinion, or both. The stability of the functioning and the legitimacy of the outcomes of this system are premised upon two key factors: the possibility of 
independent and impartial judicial review as guided by a constitution embodying a system of human rights, as discussed above, and the "quality of the public opinion," on which we need to say a few more words.

In Habermas' model, the "quality of public opinion" figures as a co-determinant in maintaining the legitimacy and stability of deliberative political processes because, as mentioned above, it functions as the primary source and ultimate control mechanism of both the political power and of the authority of the judicial institutions in reviewing its use. As can be imagined, Habermas measures the quality of public opinion not by the numeric majority of the citizens who hold it, but by the "communicative rationality" of the deliberative processes in which it is formed. More specifically, it is not the number of people who hold the same opinion on a given societal issue that bestows "democratic legitimacy" on the political influence of public opinion, but whether or not that opinion has been formed in a public sphere where communicative processes between the citizens are subject to no other constraints than those that the citizens, by virtue of their communicative competence, always and already presuppose: namely the universal and necessary presuppositions of a rational discourse where only the unforced force of the better argument holds sway. Only such an unfettered public sphere can guarantee that all relevant information and all available arguments on a given societal issue can receive a fair hearing in public debates. This, in turn, is important not because a deliberatively formed public opinion in an unfettered public sphere is assumed to be infallible at all times, but because an unfettered public sphere, coupled with a vibrant and dynamic civil society offers the citizens the opportunity to reconsider, revise, and if necessary correct their fallible opinions in the light of previously unavailable information and/or by the unforced force of a previously unavailable argument at any time (Habermas, 1996: 362-364).

Habermas introduces this dialogical model of deliberative politics neither as an accurate representation of the way in which existing democratic political structures and processes function in actual fact, nor as a normative ideal detached from the concrete reality of those structures and processes altogether. Rather, Habermas introduces this model of deliberative politics as a "rational reconstruction" of the normative self-understanding of modern democratic institutions and processes, and situates it in the grey area "between facts and norms." Seen in this grey light, any observed differences between the way that the model of deliberative democracy is depicted in theory and the way in which existing democratic political institutions and processes function in actual fact cannot and should not be understood in terms of an irreconcilable opposition between an idealistic and wishful theory of democracy, on the one hand, and the harsh and concrete reality of existing political structures, on the other. Such differences represent rather a gap between the normative ideal of modern democracy already embodied in existing democratic institutions found in most late-modern societies, and the ways in which these institutions malfunction in current social and political practice - a gap that critical, more specifically "reconstructive" social scientists can identify and document through empirical research, and democratic activists in the civil society can close through political struggles. ${ }^{(11)}$

\section{CONCLUSION}

In conclusion, I think it is fair to argue that of the three approaches exegetically summarized in this paper, the conceptual framework of Habermas' work offers a more promising solution to the problem of justification and stability under conditions of cultural diversity. To recap, Kant's solution remains 
vulnerable to contextualist criticisms because it relies on the assumption of the unity of a subjectcentered and monological conception of practical reason. Rawls' idea of an "overlapping consensus," in turn, offers an elegant and innovative response to contextualist criticisms, but it dilutes the assumption of the unity of practical reason to such an extent that, other than a coincidental meeting of the metaphysical truth claims associated with various ideological, religious, and philosophical doctrines, democracy does not appear to have a normative footing. Finally, the Habermas model of deliberative politics seems to be more promising in comparison to the previous two, because it grounds the stability and legitimacy of democratic political institutions and processes on the practical foundation of inter-subjective communication, which can fairly be assumed to be the common ground of all human beings, in every culture and historical epoch; and which indeed seems to be the socioontological commonalty to which all religious, philosophical, and ideological doctrines owe the continuity of their worldly existence in the minds and hearts of human beings. It is, after all, hard to deny the fact that since time immemorial human beings in every culture and region of the world have been transmitting, creating, and changing socio-cultural traditions of thought and faith by speaking to other human beings in order to explain themselves; listening to other human beings in order to understand them; and arguing with other human beings in order to convince them.

\section{NOTES}

1. One of the best known examples of this approach can be found in Lipset (1959), who famously postulates that a widely shared popular "belief in the legitimacy" of a democratic political structure is a social requisite for its stability. Robert Dahl's (1961: 316) notion of a "democratic creed" and Almond and Verba's (1965) notion of the "civic culture" resonate with the same idea of "legitimacy as belief." In the Marxist literature, Gramsci's (1972) notions of "ideological hegemony" and "common sense" can be read in line with this "realistic" approach to political legitimacy. More recently, Gramsci's approach found resonance both in Althusser's (1984) discussion of "ideological state apparatuses" and in Laclau and Mouffe's (Laclau and Mouffe, 1985; Mouffe, 1993, 1999) "post-Marxist" perspectives on radical democracy and agonistic pluralism.

2. The allusion is to Articles 1, 2 and 29 of the Universal Declaration of Human Rights. The conceptual differences between the notions of "legitimacy as belief" and "legitimacy as justification" as well as the implications of these differences in democratic theory have been elaborated extensively by Benhabib (1994).

3. These articles (Rawls, 1980; 1985; 1987; 1988; 1989) were later collected by Samuel Freeman in Rawls (1999). In Political Liberalism Rawls presents the argument introduced in these scattered articles in a more coherent form and the following presentation is based on that work.

4. The following formulation of the two principles of "justice as fairness" includes the revisions that Rawls introduced upon H.L.A Hart's objections to the original version that appeared in A Theory of Justice. See Hart (1973) and Rawls (1993: 289-371).

5. In an article published after Political Liberalism, Rawls (1997: 782-783n) quotes the following words of a Sudanese international lawyer, Abdullahi Anna'im (1990), as a "perfect example" of an overlapping consensus: 
The Qur'an does not mention constitutionalism, but human rational thinking and experience have shown that constitutionalism is necessary for realizing the just and good society prescribed by the Qur'an. An Islamic justification and support for constitutionalism is important and relevant for Muslims.

Non-Muslims may have their own secular or other justifications. As long as all are agreed on the principle and specific rules of constitutionalism, including complete equality and non-discrimination on grounds of gender or religion, each may have his or her own reasons for coming to that agreement.

6. For the Habermas-Rawls debate, see Habermas (1995; 1998b) and Rawls (1995). Unfortunately, time and space constraints do not allow me to include a more detailed account of this debate in this essay. A more comprehensive discussion of this debate can be found in Özbank (2003). For a useful and accessible comparison of Rawls and Habermas' approaches, see (McCarthy, 1994).

7. In addition to Rorty, who was mentioned above, the best North American examples of this contextualist critique can be found in the works of what have come to be known, variously, as "Aristotelian," "Hegelian," and/or "communitarian" authors. See, for example, MacIntyre (1981), Sandel (1984), Walzer (1983; 1994) and Taylor (1989). For a useful guide to the so-called liberalcommunitarian debate, see Mullhall and Swift (1992). A similar contextualist position has been developed, arguably with more philosophical rigor, in Germany by Gadamer (1989). Habermas' debate with Gadamer in the 1960s has had a formative influence on the latter's thoughts summarized below. The Gadamer-Habermas debate can be found, in English translation, in Ormiston and Schrift (1990). Warnke (1987; 1993) and Bernstein (1983) offer excellent secondary accounts of the Gadamer - Habermas debate.

8. For a formal derivation of the principle of universalization from the pragramatic presuppositions of rational argumentation, see Rehg (1990).

9. In developing this model Habermas follows Peters' (1993) model of societal integration, which is, unfortunately, not available in English translation. An accessible summary of this model and its political, social and legal theoretical underpinnings can be found in Habermas (1997). The following discussion is based on Habermas (1996).

10. For a useful secondary account of Habermas' position on Human Right, see Flynn (2003).

11. For a clarification of Habermas' idea of "rational reconstruction," see (1990c). For a useful critical discussion, see Alford (1985).

\section{REFERENCES}

Alford, C.F. (1985). "Is Jürgen Habermas's Reconstructive Science Really Science?" Theory and Society, 14(3): 321-340. 
Almond, G.A. and Verba, S. (1965). The Civic Culture; Political Attitudes and Democracy in Five Nations, an Analytic Study. [Boston]: Little.

Althusser, L. (1984). Essays on Ideology. London: Verso.

Anna'im, A.A. (1990). Toward an Islamic Reformation: Civil Liberties, Human Rights, and International Law. Syracuse, N.Y.: Syracuse University Press.

Benhabib, S. (1994). "Deliberative Rationality and Models of Democratic Legitimacy," Constellations, 1(1): 26-52.

Bernstein, R.J. (1983). Beyond Objectivism and Relativism: Science, Hermeneutics, and Praxis. Oxford: B. Blackwell.

Dahl, R.A. (1961). Who Governs? Democracy and Power in an American City. New Haven: Yale University Press.

Flynn, J. (2003). "Habermas on Human Rights: Law, Morality, and Intercultural Dialogue," Social Theory and Practice," 29(3): 431-457.

Gadamer, H.G. (1989). Truth and Method (2nd ed.). New York: Crossroad.

Gramsci, A., Hoare, Q., and Nowell-Smith, G. (1972). Selections from the Prison Notebooks of Antonio Gramsci (1st ed.). New York: International Publishers.

Habermas, J. (1979). "What is Universal Pragmatics?” T. McCarthy (trans.), in Communication and the Evolution of Society. Boston: Beacon Press.

----- (1984). “The Theory of Communicative Action,” T. McCarthy (trans.), vol. 1, Reason and Rationalization of Society. Boston: Beacon Press.

----- (1990a). "Discourse Ethics: Notes on a Program of Philosophical Justification," in C.N. Lenhardt and S. Weber (trans.), Moral Consciousness and Communicative Action: 43-116. Cambridge, Mass.: MIT Press.

(1990b). Moral Consciousness and Communicative Action. C.N. Lenhardt and S. Weber (trans.). Cambridge, Mass.: MIT Press.

----- (1990c). "Reconstruction and Interpretation in the Social Sciences," in C.N. Lenhardt and S. Weber (trans.), Moral Consciousness and Communicative Action. Cambridge, Mass.: MIT Press.

----- (1993a). Justification and Application: Remarks on Discourse Ethics. C. Cronin (trans.). Cambridge, Mass.: MIT Press.

----- (1993b). "Remarks on Discourse Ethics," in C. Cronin (trans.), Justification and Application: Remarks on Discourse Ethics. Cambridge, Mass.: MIT Press. 
- (1995). "Reconciliation through the Public Use of Reason: Remarks on John Rawls' Political Liberalism," The Journal of Philosophy, 92(3): 109-131.

(1996). Between Facts and Norm: Contributions to a Discourse Theory of Law and Democracy. W. Rehg (trans.). Cambridge, Mass.: MIT Press.

(1997). "A Conversation about Political Theory," in S. Rendall (trans.), A Berlin Republic: Writings on Germany: xxiv, 187. Lincoln: University of Nebraska Press.

------ (1998a). The Inclusion of the Other: Studies in Political Theory. Cambridge, Mass.: MIT Press.

----- (1998b). “ 'Reasonable' versus 'True' or the Morality of Worldviews," in C. Cronin and P. De Greiff (eds.), The Inclusion of the Other: 75-101. Cambridge, Mass: MIT Press.

----- (2001). On the Pragmatics of Social Interaction: Preliminary Studies in the Theory of Communicative Action, B. Fultner (trans.). Cambridge, Mass.: MIT Press.

Hart, H.L.A. (1973). "Rawls on Liberty and Its Priority," University of Chicago Law Review, 40(3): 551-555.

Johnson, R. (2004). “Kant's Moral Philosophy," The Stanford Encyclopedia of Philosophy Spring. From <http://plato.stanford.edu/archives/spr2004/entries/kant-moral/>.

Kant, I. (1991a). “An Answer to the Question: What is Enlightenment?" in H. Reiss (ed.), H.B. Nisbet (trans.), Kant: Political Writings (second enlarged edition): 54-63. Cambridge: Cambridge University Press.

------ (1991b). "Idea for a Universal History with a Cosmopolitan Purpose," in H. Reiss (ed.), H.B. Nisbet (trans.), Kant: Political Writings ( $2^{\text {nd }}$ enlarged edition): 41-53. Cambridge: Cambridge University Press.

------ (1991c). “The Metaphysics of Morals," in H. Reiss (ed.), H.B. Nisbet (trans.), Kant: Political Writings ( $2^{\text {nd }}$ enlarged edition): 131-175. Cambridge: Cambridge University Press.

----- (1991d). "On the Common Saying: 'This May Be True in Theory but It Does Not Apply in Practice," in H. Reiss (ed.), H.B. Nisbet, (trans.), Kant: Political Writings ( $2^{\text {nd }}$ enlarged edition): 6192. Cambridge: Cambridge University Press.

----- (2005). Groundwork for the Metaphysics of Morals. T. Kingsmill Abbott and L. Denis (eds.). Peterborough, Ont. ; Orchard Park, NY: Broadview Press.

Laclau, E. and Mouffe, C. (1985). Hegemony and Socialist Strategy: Towards a Radical Democratic Politics. London: Verso.

Lipset, S.M. (1959). "Some Social Requisites of Democracy: Economic Development and Political Legitimacy,” The American Political Science Review, 53(1): 69-105. 
MacIntyre, A. C. (1981). After Virtue: A Study in Moral Theory. Notre Dame, IN: University of Notre Dame Press.

McCarthy, T. (1994). "Kantian Constructivism and Reconstructivism: Rawls and Habermas in Dialogue," Ethics, 105(1): 44-63.

Mouffe, C. (1993). The Return of the Political. London ; New York: Verso.

------ (1999). “Deliberative Democracy or Agonistic Pluralism?” Social Research, 66(3): 745-758.

Mulhall, S. and Swift, A. (1992). Liberals and Communitarians. Oxford, UK; Cambridge, USA: Blackwell.

Ormiston, G.L. and Schrift, A.D. (1990). The Hermeneutic Tradition: From Ast to Ricoeur. Albany, NY: State University of New York Press.

Özbank, M. (2003). "Cultural Diversity and Political Stability: Reflections on Rawls-Habermas Debate.” Paper presented at the World Philosophy Congress.

Peters, B. (1993). Die Integration Moderner Gesellschaften (1. Aufl. ed.). Frankfurt am Main: Suhrkamp.

Rawls, J. (1971). A Theory of Justice. Cambridge, Mass.: Belknap Press of Harvard UniversityPress.

------ (1980). “Kantian Constructivism in Moral Theory,” The Journal of Philosophy, 77(9): 515-572.

----- (1985). “Justice as Fairness: Political not Metaphysical,” Philosophy and Public Affairs, 14(3), 223-251.

----- (1987). “The Idea of an Overlapping Consensus," Oxford Journal of Legal Studies, 7(1).1-25.

----- (1988). "The Priority of Right and Ideas of the Good," Philosophy and Public Affairs, 17(4): 251-276.

----- (1989). "The Domain of the Political and Overlapping Consensus," New York University Law Review, 64: 233-255.

----- (1993). Political Liberalism. New York: Columbia University Press.

----- (1995). "Political Liberalism: Reply to Habermas," The Journal of Philosophy, 92(3): 132-180.

----- (1997). “The Idea of Public Reason Revisited,” The University of Chicago Law Review, 64(3): 765-807.

Rawls, J. and Freeman, S.R. (1999). Collected Papers. Cambridge, Mass.: Harvard University Press. 
Rehg, W. (1990). "Discourse and the Moral Point of View: Deriving a Dialogical Principle of Universalization," Inquiry, 34: 27-48.

Reiss, H. (1991). “Introduction," in H. Reiss (ed.), Kant: Political Writings (2nd enlarged edition): 140. Cambridge Cambridge University Press.

Rorty, R. (1979). Philosophy and the Mirror of Nature. Princeton: Princeton University Press.

------ (1989). Contingency, Irony, and Solidarity. Cambridge, New York: Cambridge University Press.

------ (1991). Objectivity, Relativism, and Truth. Cambridge, New York: Cambridge University Press.

----- (1998). Achieving Our Country: Leftist Thought in Twentieth-century America. Cambridge, Mass.: Harvard University Press.

Sandel, M.J. (1984). Liberalism and Its Critics. New York: New York University Press.

Taylor, C. (1989). Sources of the Self: The Making of the Modern Identity. Cambridge, Mass.: Harvard University Press.

Walzer, M. (1983). Spheres of Justice: A Defense of Pluralism and Equality. New York: Basic Books.

----- (1994). Thick and Thin: Moral Argument at Home and Abroad. Notre Dame: University of Notre Dame Press.

Warnke, G. (1987). Gadamer: Hermeneutics, Tradition, and Reason. Stanford, Calif.: StanfordUniversity Press. (1993). Justice and Interpretation (1st MIT Press ed.). Cambridge, Mass.: MIT Press. 